\title{
GOVERNMENT DISASTER RESPONSE AND NARRATIVE RETROSPECTION: A COMPARATIVE STUDY OF THE ELECTORAL IMPACTS IN DENMARK AND SWEDEN OF THE 2004 TSUNAMI
}

\author{
OLIVIER RUBIN \\ Department of Social Sciences and Business, Roskilde University, Denmark
}

\begin{abstract}
This paper investigates the nexus between disaster response and voting behaviour through a comparative study of the electoral dynamics in the immediate aftermath of the 2004 Tsunami in Denmark and Sweden. The paper addresses three hypotheses of retrospection: (i) blind retrospection where voters primarily take the disaster impacts into account; (ii) mediated retrospection where voters primarily take the quality of the disaster response into account; and (iii) narrative retrospection where voters primarily take the dominant political narrative of the disaster into account. The results suggest that voters did not appear to immediately punish the Danish and Swedish governments for the Tsunami despite the severe impacts and the widespread public disapproval of the governments' disaster responses. The concept of narrative retrospection shows how there was limited pressure to politicize the government's disaster management efforts in Denmark, while the brunt of the political blame in Sweden occurred more than a year after the Tsunami.

Keywords: Tsunami, voting, retrospection, Denmark, Sweden.
\end{abstract}

\section{INTRODUCTION}

Sunday morning December $26^{\text {th }}, 2004$ a huge Tsunami swept the coasts of Indonesia, Sri Lanka, India and Thailand. More than two hundred thousand people perished in the waves, and for the countries in the immediate vicinity of the Indian Ocean earthquake, it constituted the worst natural disaster for centuries. However, what is less acknowledged is the fact that the Tsunami also constituted the worst natural disaster in modern time for countries far removed from the earthquake's epicentre. For Denmark and Sweden, for example, the Tsunami was the deadliest natural disaster for more than a hundred years. Due to the many vacationing Scandinavians in Thailand, Sweden lost 543 citizens and Denmark lost 46 to the Tsunami. As a comparison, during the entire last century only 35 people in Sweden and 24 people in Denmark have succumbed to natural disasters [1]. In other words, the Tsunami brought home the suffering of natural disasters to a Nordic region that had historically been spared these types of catastrophes.

This paper sets out to investigate the nexus between disaster response and voting behaviour through a comparative study of the electoral dynamics in the immediate aftermath of the 2004 Tsunami in Denmark and Sweden. The paper introduces the concept of (narrative retrospection) to investigate situations where Danish and Swedish voters do not only take the Tsunami impacts (blind retrospection) or the quality of the disaster response into account (mediated retrospection) but where they are influenced the dominant political narratives. In Denmark there was no pressure to politicize the government's disaster management efforts, and accordingly the critique was very much restricted to the bureaucratic level of administrative (technocratic) flaws, whereas the media and opposition targeted the government much more directly in Sweden. However, the brunt of this critique occurred more than a year after the Tsunami, showing that political narratives are on-going and not necessarily restricted to the period right after the disaster. The paper argues that studies solely 
set up to capture short-term disaster dynamics of cause and effect would overlook these vital longer term political dynamics. The paper is structured as follows.

First, the three theories of retrospection are briefly discussed and their appertaining hypotheses laid out. Secondly, the case and research design is described. The analytical part consists of three sections addressing each of the three hypotheses.

\section{THE THREE THEORIES AND HYPOTHESES OF VOTER RETROSPECTION}

The theory of retrospective voting assumes that voters evaluate the past performance of the incumbent government when deciding their vote. Traditionally, retrospection have been divided into two separate dynamics: simple (or blind) retrospection, referring to the fact that the electorate evaluates the incumbent government based on each voter's own situation regardless of whether the government's policies have actually influenced that situation; or mediated retrospection, where voters judge the incumbent government based on its policies [2]. There has recently been increasing interest in analysing voting behaviour during natural disasters. Several studies have documented that indeed voters blindly punish governments over events that governments have very little influence over [3]-[5]. More specifically with respect to natural disasters, voters appear to electorally punish the incumbent government for merely presiding over a natural hazard even though the hazard has little to do with the actions of the government [3], [6]-[8]. Mediated retrospection adds an extra layer of voting complexity, because voters also base evaluations on mediated judgments on the actions taken by governments on particular issues. In the context of disasters, several detailed studies of the political effects of natural disasters have found that voters do indeed take into account the actions of the government [3], [9]-[12].

I have recently argued for the relevance of a third complimentary theory of retrospection termed narrative retrospection (Rubin [13]). Here, any electoral effect of a disaster depends crucially on the extent to which the disaster is turned into a political narrative around which different political actors position themselves. Major natural disasters (and other crises) tend to give rise to conflicting interpretations based on a plurality of political values and interests. Thus, focus is less on the natural disaster itself and more on the way it is used (or abused) politically. The causes and consequences of natural disasters are not crystal clear for voters, not just because of their myopic and retrospective voting behaviour, but because they are communicated in a political arena where different myths, narratives and symbols fight for dominance. Disasters have important symbolic power, and sociocultural contexts play a key role in shaping political outcomes. Myths and symbols should not be understood as imaginary or unreal folklore, but instead as socio-political narratives that provide meaning and comfort in the wake of a natural disaster [14]. Political narratives can be understood as narratives that emerge from formal political forums, are produced by politicians and public official, contain themes considered political, and are reproduced in the public debate [15]. Such definition, of course, leaves unanswered the essential question of what could be considered political. This paper argues that for a theme to be considered political (and not just trivial) it must both be contested by other key political actors as well as prioritized in political arenas in competition with other issues. An interesting implication of narrative retrospection is therefore that natural disasters might actually have greater long-term political consequences than it has immediate short-term political consequence. The natural disaster may awaken feelings, moods and particular narratives that mature and evolve in the aftermath of the disaster, leading to political changes not necessarily imminent but which slowly materialize. Thus, retrospective voting theory should also pay due attention to the political narratives that are constituted in the wake of disasters, and investigate the extent to which disasters are used actively in forming these political narratives. 


\section{RESEARCH DESIGN}

Denmark and Sweden are very similar along most socio-political dimensions: both countries are mature liberal democracies with vocal opposition parties and a free and critical media. They also have multi-party systems in which no single party is likely to hold an absolute majority; thus, the governing norm is coalition governments that are not met with a vote of non-confidence by the parliament. Voter retrospection has been shown to function best in such pluralistic and competitive political environments [16], [17]. An interesting question is whether we can observe the same voter dynamics in the wake of the Tsunami.

The methodological caveat with many previous studies on disasters and voter retrospection relates to the difficulties of teasing out the exogenous effect (the natural hazard) from the more endogenous effects (inadequate preventive policies). In other words, do voters punish the government for extreme rainfall (an exogenous effect) or do they in fact punish the government for the fact that the extreme rains overwhelmed the country's worn and unmaintained sewerage system (an endogenous effect)? What makes the 2004 Tsunami shock unique in this study is that it is related to the political dynamics in Denmark and Sweden - countries that are far removed from the epicentre of the disaster. This entails that the disaster shock can analytically be separated from ex ante disaster preventive policies - both spatially and in terms of responsibility. Hence, any electoral movement rooted in the disaster can be attributed the public perception of their disaster management efforts ex post. Retrospection is related to the governments' handling of the disaster after December $26^{\text {th }}$, which makes the Tsunami as close to an exogenous shock as is realistically possible.

The three complimentary theories of retrospection generate different hypotheses that can be tested in the comparative study of Sweden and Denmark. The theory of blind retrospection would predict that we would likely expect to see voter movements immediately after the Tsunami, and that the incumbent government would lose electoral support in this process. The theory of mediated retrospection would focus on another predictor of voter movements. Here, the public perception of government responses to the Tsunami is the main determinant of the electoral impact. The theory of narrative retrospection emphasises the importance of political narratives of the Tsunami as the main predictor of voter movement. Here, voter retrospection is not only related to the direct disaster impacts; nor is it merely dependent on the public perception of governments' disaster policies. Instead, it is related to the dominant political narratives that emerge from the Tsunami. The hypotheses can thus be formalized:

- $\quad$ H1: The incumbent governments in Denmark and Sweden will lose electoral support in the immediate aftermath of the Tsunami (blind retrospection).

- $\quad$ H2: The incumbent governments in Denmark and Sweden will lose electoral support in the aftermath of the Tsunami, provided there is a widespread critical public perception of the governments' disaster response (mediated retrospection).

- H3: The incumbent governments in Denmark and Sweden will lose electoral support from the Tsunami, provided that the critical public perception of the governments' Tsunami response is translated into a political narrative (narrative retrospection).

The methodological requirements to assess the hypotheses differ. $\mathrm{H} 1 \mathrm{can}$ be addressed in purely quantitative terms by drawing on an indicator of voter movements. The validity of $\mathrm{H} 2$ can best be assessed by a combination of qualitative and quantitative data that together provide an indication of the public perception of the Tsunami response. H3 primarily relies on qualitative data to assess whether the Tsunami response is actually elevated to constitute 
an important political narrative. The more detailed operationalization will be discussed in the relevant analytical subsections.

\section{RESULTS}

\subsection{Blind Retrospection (H1)}

Blind retrospection predicts that disasters will undermine support for the incumbent government (ceteris paribus) regardless of the quality of government response and the political narrative of the disaster. The hypothesis derived from blind retrospection, therefore, lends itself well to testing based on quantitative data from election polls. Polls appear to be the most beneficial way to gather sufficient data to make robust statistical inferences of voter support. In the context of this study, polling has methodological advantages over actual election results: (i) polls are conducted more frequently meaning that voter movements can more easily be identified immediately following the disaster; (ii) voters can use polls as a cost-free channel to display government dissatisfaction. It is therefore reasonable to expect polls to be more sensitive to sudden shocks. Opinion polls in both Sweden and Denmark are conducted frequently by unpartisan organizations. The paper relies on Gallup [18], as provider of the Danish data and Ipsos/Temo Välgerbarometer [19], as a provider of the Swedish data. Both organizations have a long track-record of unbiased election polling and they gather data on voter movements on a monthly basis. The results for Denmark and Sweden have been illustrated in Fig. 1 and Fig. 2. The figures illustrate the monthly movements in government support in the six months prior to the Tsunami (which is marked with a red dot) and in the six months following the Tsunami.

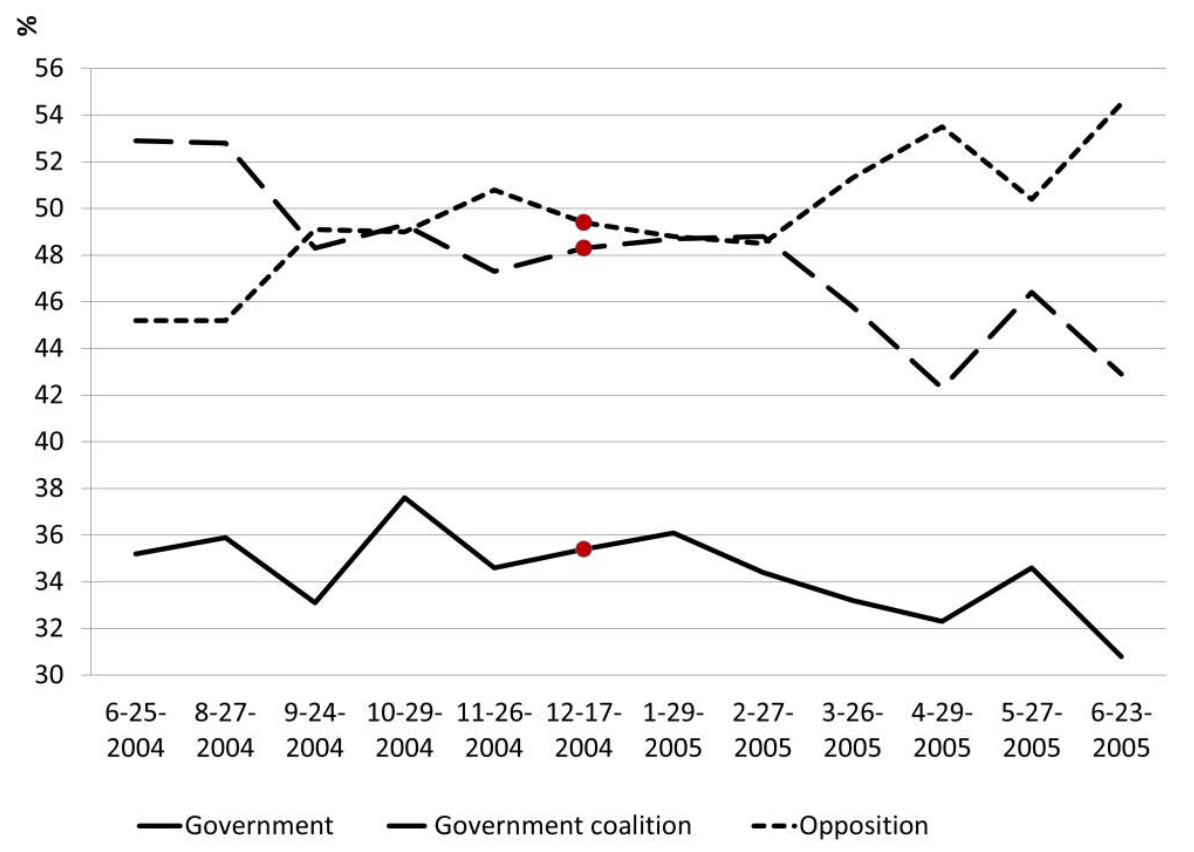

Figure 1: Danish voter support for the government, the government coalition, and the opposition in the 12-month Tsunami period. 


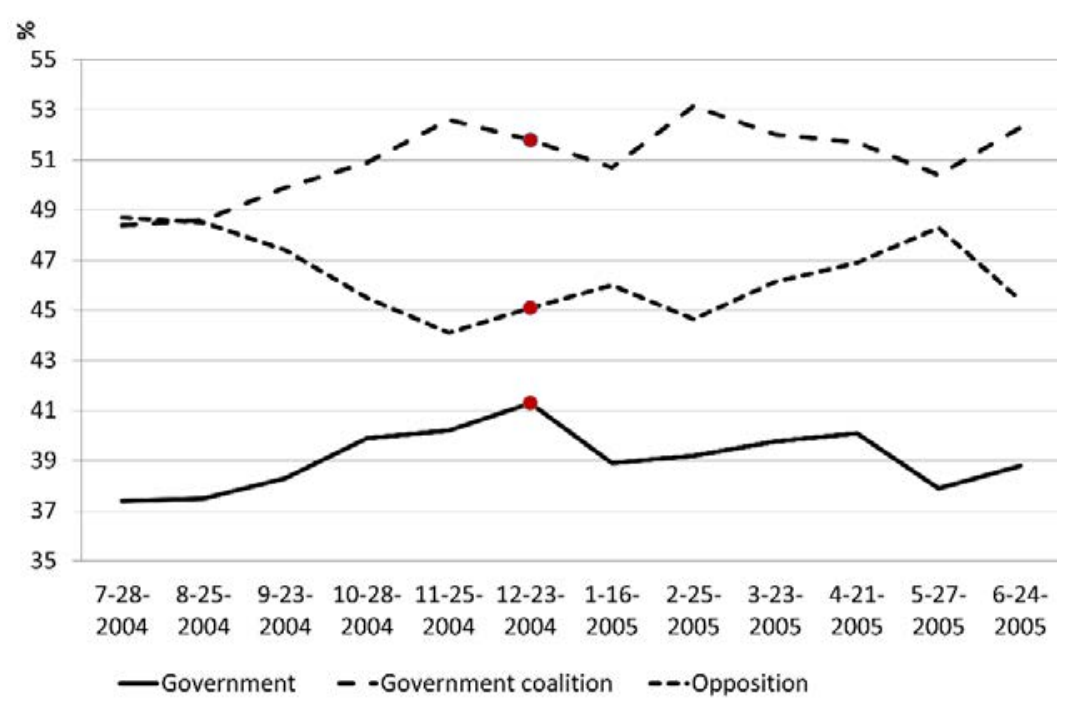

Figure 2: Swedish voter support for the government, the government coalition, and the opposition in the 12-month Tsunami period (excl. July).

In both cases, the two figures reveal that it is very difficult to discern any clear decline in voter support for the incumbent governments. More rigorous statistical analysis also provides little support for the hypothesis.

In the first analysis, we are interested in identifying a sudden downward movement in government support following the Tsunami. Calculating the two-standard deviations from the mean is a common way to identify drops that with much certainty cannot be ascribed random (unexplained) movements. The means are derived from two different reference periods for each country: (i) one short period consisting of the same 12 months as specified above; and (ii) a longer multi-year period (in Denmark the period stretched between the two general elections in 2002 and 2007, and in Sweden the period went from 2002 to the general election in 2006). Regardless of reference period, neither country displayed a significant drop in government support following the Tsunami.

In the second analysis, we focus on whether fluctuations (the variance) in the Tsunami period differed significantly from that of other periods without an equivalent disaster shock (based on Levene's F-tests). In both the Danish and the Swedish case, the twelve-month Tsunami-period was compared to the twelve-month periods just before and just after the Tsunami period. Hence, all the different periods contain 12 polling results with monthly intervals. In both the Danish and the Swedish case, it appeared that the variance in the Tsunami periods did not differ significantly from the variance in other periods. The Danish Tsunami period also included a general election. To take into account any effects hereof, the Tsunami period was compared with an equivalent period containing the 2007 election. Again, however, the two periods did not appear to differ significantly with respect fluctuations in government support (although the mean differed between the two periods as 
expected). In short, the Tsunami did not appear to reduce electoral support for the government.

\subsection{Mediated Retrospection (H2)}

The lack of empirical support for H1 could be explained by mediated retrospection: the governments did not lose support because most voters perceived the government responses to be adequate. Here we will test the validity of this hypothesis (H2).

In Denmark, all major newspaper carried stories of the chaos that ensued in the wake of the Tsunami, and the reporting carried several stories about the inadequacy of the Danish authorities' support right from the start, in particular with regards getting citizens back home. Several opinion editorials and articles criticized the many systemic flaws with the disaster management efforts. These related to a lack of coordination between the Foreign Ministry, the Embassies and the police; an insufficient staffing (both medical and organizational) on the ground; weak information dissemination; the Foreign Ministry's unnecessary delay in taking in the full scope of the disaster; and the sluggishness in establishing and dispatching a task force [20]-[22].

In Sweden, the media was also highly critical of the government's disaster response. The criticism mainly addressed systemic failures: articles pointed to the absence of large-scale evacuation plans for citizens abroad; the lack of ministerial cooperation with the police; inadequate information dissemination; flawed institutional setups for the emergency force; and a widespread passivity in all levels of the administration in the first days after the disaster [23].

The negative media coverage had a clear impact on the general public perception. One of the largest Swedish tabloids, AftonBladet, asked their readers to assess the government efforts. Despite sharing many of the government's left-leaning positions, $64 \%$ of the 65,000 readers that participated in the survey answered that indeed the Swedish government was to blame for the many mistakes made [24]. This is supported by a more scientific poll where $71 \%$ of the respondent expressed the view that there were fairly strong reasons to be critical of the Swedish management of the disaster [25]. The Danish polls also point in the same direction although less forcefully, which might be attributed to the spinning of the question posed. Gallup (commissioned by the Foreign Ministry) asked whether the respondent agreed or disagreed with the statement that the efforts of Danish authorities had been acceptable/appropriate. $57 \%$ of the surveyed agreed with the statement while $30 \%$ disagreed. In a comparative perspective the number of respondents disagreeing was sizable: only $13 \%$ and $14 \%$ disagreed when the same question was posed with regards the travel agencies and the insurance companies [26]. Thus, the evidence overwhelming suggests that indeed the governments' Tsunami efforts were subject to extensive public scrutiny, and that the broader electorate to a large extent held the governments responsible for inadequate disaster responses.

\subsection{Narrative Retrospection (H3)}

So far it appears that the electorate did not blindly punish the Danish and Swedish governments for the Tsunami (H1) despite the severe impacts and the widespread public disapproval of the governments' disaster responses $(\mathrm{H} 2)$. Narrative retrospection would speculate that this might be because the dominant political narrative did not encompass the Tsunami in any forceful manner. The investigation of the Danish and Swedish narratives will primarily rely on a qualitative document analysis (newspaper articles and government 
reports). In the following, I have opted for only referencing the most essential articles and reports in order to align the paper with the paper format of the proceedings. The full paper with all newspaper references can be submitted on request.

In Denmark, the Tsunami was subsumed under an existing political narrative depicting the PM as a powerful and reliable leader. A Gallup poll conducted a month after the Tsunami revealed that $38 \%$ of the electorate very much agreed with a characterization of the PM as a resolute and steadfast politician while only $6 \%$ ascribed the same characteristics to the leader of the opposition [27]. The widespread public disapproval of the government's disaster management efforts did not stick politically to the PM. He succeeded in forming a humanitarian narrative rather than a political narrative. In his New Year's address to the nation, a political tradition in Denmark (but not in Sweden), the PM explicitly removed the Tsunami from the party-political domain. As is routine, the PM's speech had been taped in advance ready to be broadcast on January $1^{\text {st }}, 2005$. A few hours before airing, however, the PM decided to discard the pre-recorded speech. Instead, he gave a very short speech (supposedly written that very afternoon) that only dealt with the vast suffering brought by the Tsunami. He told the nation that in the light of the horrific tragedy, he had decided to put everyday politics aside, and he then continued delivering a speech of hope and comfort. Uncharacteristically, the PM's speech did not spark a single critical remark from the opposition parties. Even the opposition leader applauded the speech as the right thing to do. So while the media coverage was generally critical of the government's response, it did not turn into a political critique; instead it was confined to a systemic critique of the administrative procedures. Unlike the Swedish PM, the Danish PM was never forced to apologize personally for the government's inadequate disaster management. The leader of the opposition was reluctant to break the party truce spurred on by the Tsunami. He was furious at a newspaper for choosing to publish an interview too close to the Tsunami catastrophe where he outlined his tax plan. At a political rally two weeks after the Tsunami, the political leaders agreed not to engage in the usual political exchanges in the light of the tragedy. When the party truce was finally broken, the opposition returned to domestic issues such as tax, immigration and welfare reforms [28]. The PM was so confident that the government's handling of the Tsunami would not have adverse political consequences that he called for a general election just three weeks after the Tsunami (to be held February $\left.8^{\text {th }}, 2005\right)$. Another strong indication that the Tsunami did not play a large part in the political narratives was the fact that it did not figure in Aalborg University and Gallup's otherwise comprehensive election survey. They polled on a wide number of issues but the handling of the Tsunami was not one of them [29]. Although the main campaign themes covered major issues such as immigration and taxation reforms as well as minor issues such as a 0.06 Euro levy on the Danish credit cards, at no point did it encompass the inadequate government response to the Tsunami [28]. Even the release on May 24th, 2005 of a Danish evaluation-report of the Tsunami response was a non-event. Unlike the Swedish evaluation report (see below), the Danish report was compiled by the Foreign Ministry itself, and its release generated very limited media-coverage. The report did acknowledge several systemic errors, and listed 30 recommendations for bolstering future disaster responses for citizens abroad. It did not, however, place a political responsibility. The opposition also refrained from placing any political responsibility, and political parties from both sides of the aisle applauded the report, and emphasized the need to look ahead. In sum, the public criticism in Denmark was not channelled into a political critique despite the fact that the election took place just 5 weeks after the Tsunami. The PM effectively succeeded in depoliticizing the Tsunami. The opposition, it appeared, did not contest the government's handling of 
the Tsunami, and it did not prioritize this political theme, stressing instead other political issues such as immigration and taxation reforms.

The political dynamics in the Swedish case were slightly different. In Sweden - more so than in Denmark - the administrative failures were only part of a larger narrative that also included accusations of political incompetence. The Foreign Minister, in particular, was heavily criticized [30]. Several media outlets reported how the Foreign Minister went to the theatre twenty hours after the Tsunami despite initial reports of more than hundred thousand fatalities, and that she did not show up for work in the Ministry until thirty-one hours after the Tsunami [25], [30]. In subsequent interviews, she admitted having absolutely "no idea what Phuket was' and that she was unaware that Thailand was such a popular tourist site for Swedes [31]. In defence of the belated disaster response, the Foreign Minister was quoted saying that she did not follow news on her days off. The actions and statements of the Foreign Minister drew heavy criticism and public outrage that transcended the more systemic critique of the administrative procedures [30]. The government as a whole was also subject to a more direct criticism. While initially the opposition emphasized national unity (as in Denmark) it slowly became increasingly critical of the government. Ironically, it appeared that the traditionally apolitical Swedish King might have provided a window of opportunity for politicizing the Tsunami. The King remarked in an emotional interview about the Tsunami on January $10^{\text {th }}$ that "in certain situations it is better to act than to do nothing. It is better to call for an ambulance and then send it back if it is not needed anyway. But too often in Sweden nobody dares to take responsibility" [32]. The statement was clearly a badly concealed critique at the government. Subsequently, the opposition also started attacking the government by claiming that it lacked competence, and that it did not comprehend that injured citizens needed to come home and be treated. It went as far as to argue that 'had Sweden had a centre-right government, fewer citizens would have died' [33]. The political actions of the PM also suggest that the Tsunami had turned into a political issue. The PM reflected blame by accusing the Thai authorities of not alerting him fast enough, and by criticizing the Foreign Ministry (singling out two particular civil servants) for sitting on vital information for too long. The Swedish PM also decided - unlike the Danish PM who dispatched the Minister for Development - to inspect the destruction in Thailand personally in the immediate aftermath of the Tsunami. However, the critique of the government never got real traction on the political agenda, and the political and media interest in the government's Tsunami-response withered away after the initial month. However, the interest in the Swedish government's handling of the disaster returned with a vengeance in December 2005 with the release of the Tsunami-evaluation report [34]. The independent commission-report placed much of the responsibility for the belated response at the feet of the PM. The report sparked a massive critique from the media and opposition calling for the PMs resignation but stopping short of an actual vote of no confidence [30], [35]. The Swedish political dynamics underscores an important point: whereas voter retrospection with respect to the Tsunami and government policies is often assumed to be more or less instantaneous, a political narrative is a continuous story thus allowing for retrospection and politicization long after the Tsunami has occurred. The government has speculated that the critical political narrative might have played a role in the 2006 electoral defeat where the government was ousted after 12 years in power [36]. A recent study has indeed found a small negative impact $(0.7 \%)$ on the government's vote share in the municipalities affected by the tsunami (after controlling for other factors) [9]. This rather modest but significant impact of the Tsunami is supported by the fact that the management of the Tsunami never really emerged as a salient issue in the 2006 election campaign. There is also strong evidence that the unfavourable 
Tsunami narrative that stuck to the Foreign Minister was a contributing factor in her resignation in 2006 [37].

It is beyond the scope of the paper to analyse in-depth why the Tsunami never got real traction on the political agenda. Natural disasters and disaster management are not traditionally high priority issues in Denmark and Sweden (recall the negligible natural disaster fatalities during the last century), and political processes and disputes are primed towards other issues such as taxes, migration, unemployment, and so on. Despite high fatalities and widespread disapproval of the governments' handling of the disaster (strong predictors for voter retrospection), the Tsunami also contained characteristics that pulled in the opposite direction: it did not impact the Danish and Swedish societies or economies; disasters were not part of mainstream political agendas, and political actors had no reason to believe that disasters would become a salient issue in the immediate future. However, more empirical research is needed to determine the validity of these speculations.

\section{CONCLUSION}

In this comparative case, retrospective voters appear not only to take the Tsunami impact or the quality of the disaster policies into account but also the political narratives that are spun around the Tsunami. In this paper, three hypotheses were tested. There was little empirical support for the proposition that voters in Denmark and Sweden blindly punished the incumbent governments for the impacts of the Tsunami. Neither was there much support for the proposition that voters reacted to the widespread public criticism of the governments' responses to the Tsunami. The paper argued that a retrospective voter might not be able to assess in great details the government's disaster policies (mediated retrospection) but would instead consider the narratives surrounding the disaster. In Denmark there was no pressure to make the government's disaster management part of a political narrative, and the critique was very much restricted to the systemic level of administrative (technocratic) flaws. In Sweden, on the contrary, this systemic critique was supplemented with a political critique levelled at the government directly. However, the brunt of this critique occurred more than a year after the Tsunami, underscoring the advantage of linking voter retrospection to prevailing political narratives (rather than specific policies or disaster impacts): political narratives are on-going and their effects are not necessarily restricted to the period right after the disaster.

\section{REFERENCES}

[1] EM-DAT data. Available at: http://www.emdat.be. Accessed on: 28 Dec 2016.

[2] Fiorina, M., Retrospective Voting in American National Elections, Yale University Press: New Haven, 1981.

[3] Healy, A. \& Malhotra, N., Random events, economic losses, and retrospective voting: Implications for democratic competence. Quarterly Journal of Political Science, 5(2), pp. 193-208, 2010.

[4] Achen, C. \& Bartels, L., Blind retrospection: Electoral responses to drought, flu, and shark attacks. Presented at The Annual Meeting of the American Political Science Association, Boston, 2004.

[5] Wolfers, J., Are Voters Rational? Evidence from Gubernatorial Elections. Research Paper No. 1730, Graduate School of Business, Stanford University, 2002.

[6] Carlin, R., Love, G. \& Zechmeister, E., Natural Disaster and Democratic Legitimacy: The Public Opinion Consequences of Chile's 2010 Earthquake and Tsunami. Political Research Quarterly, 67(1), pp. 3-15, 2014. 
[7] Gasper, J. \& Reeves, A. Make it rain: Retrospection and the attentive electorate in the context of natural disasters. American Journal of Political Science, 55(2), pp. 340-355, 2011.

[8] Cole, S., Healy, A. \& Werker, E., Do voters demand responsive governments? Evidence from Indian disaster relief. Journal of Development Economics, 97(2), pp. 167-181, 2012.

[9] Eriksson, L., Winds of change: Voter blame and storm Gudrun in the 2006 Swedish parliamentary election. Electoral Studies, 41, pp. 129-142, 2016.

[10] Remmer, K., Exogenous shocks and democratic accountability: Evidence from the Caribbean. Comparative Political Studies, 47(8), pp. 1158-1185, 2014.

[11] Bechtel, M. \& Hainmueller, J., How lasting is voter gratitude? An analysis of the short and long-term electoral returns to beneficial. American Journal of Political Science, 55(4), pp. 851-867, 2011.

[12] Healy, A. \& Malhotra, N., Myopic voters and natural disaster policy. American Political Science Review 103

[13] Rubin, O., Natural disasters and politics. Disaster Research: Multidisciplinary and International Perspectives, eds R. Dahlberg, O. Rubin \& M. Vendelø, Routledge: Abingdon, pp. 82-96, 2015.

[14] Hart, P., Symbols, rituals and power: The lost dimensions of crisis management. Journal of contingencies and crisis management, 1(1), pp. 36-50, 1993.

[15] Shenhav, S., Political narratives and political reality. International Political Science Review, 27(3), pp. 245-262, 2006.

[16] Gasper, J. \& Reeves, A., Governors as opportunists: Evidence from disaster declaration requests. Working Paper for the American Political Science Association, 2010.

[17] Reeves, A., Political disaster: Unilateral powers, electoral incentives, and presidential disaster declarations. Journal of Politics, 73(4), pp. 1142-1151, 2011.

[18] Gallup Politisk Indeks. Available at http://www2.tns-gallup.dk/nyhedscenter/ statistik/politisk-indeks.aspx. Accessed on: 28 Dec. 2016.

[19] Ipsos/Temo Välgerbarometer. Available at: http://ipsos.se/opinion. Accessed on: 28 Dec. 2016.

[20] Berlingske, Udenrigsministeriet erkender fejl. Available at: http://www.b.dk/danmark/ udenrigsministeriet-erkender-fejl. Accessed on: 28 Dec. 2016.

[21] Information, Krisehåndtering for begyndere. Available at: http://www.information.dk/ 101448. Accessed on: 28 Dec. 2016.

[22] Ritzau, Ministerium smølede med krisehjælp, Available at: Infomedia.dk. Accessed on: 28 Dec. 2016.

[23] Aftonbladet, Ansvarlöst af regeringen. Available at: http://www.aftonbladet.se/ ledare/article10523883.ab. Accessed on: 28 Dec. 2016.

[24] Aftonbladet, Aftonbladets läsare: regeringen bär ansvaret. Available at http://www.aftonbladet.se/nyheter/article10528709.ab. Accessed on: 28 Dec, 2016.

[25] Strömbäck, J. \& Nord, L., Mismanagement, mistrust and missed opportunities: a study of the 2004 tsunami and Swedish political communication. Media, Culture \& Society, 28(5), pp. 789-800, 2006.

[26] Udenrigsministeriet, Evaluering af den samlede danske håndtering af flodbølgekatastrofen i Asien. Available at: http://docplayer.dk/1114885-Evalueringaf-den-samlede-danske-haandtering-af-flodboelgekatastrofen-i-asien.html. Accessed on: 28 Dec. 2016. 
[27] Aalborg University Survey Bank, Valgundersøgelsen. Available at: http://bank1. surveybank.aau.dk/webview. Accessed on: 28 Dec. 2016.

[28] Pedersen, K., The 2005 Danish general election: A phase of consolidation. West European Politics, 28(5), pp. 1101-1108, 2005.

[29] Valgundersøgelsen 2005 Teknisk rapport. Available at: http://files.portal.aau. $\mathrm{dk} /$ filesharing/download?filename $=$ aau/adm/survey/ /pub/SurveyBank/Valg/2005/M odul_1_Oversigt_over_datamaterialet.pdf. Accessed on 28 Dec. 2016.

[30] Óden, T., Ghersetti, M. \& Walling, U., Tsunamins genomslag en studie av svenska mediers bevakning. kbm's temaserie 13. Available at http://rib.msb.se/Filer/ pdf\%5C26159.pdf. Accessed on: 28 Dec. 2016.

[31] Dagens Nyheter, Tsunami okänt begrepp på UD. Available at: http://www.dn.se/ nyheter/politik/tsunami-okant-begrepp-pa-ud. Accessed on: 28 Dec 2016.

[32] Dagens Nyheter, Över ett dygn gick innan kungen informerades. Available at: http://www.dn.se/nyheter/sverige/over-ett-dygn-gick-innan-kungen-informerades. Accessed on: 28 Dec. 2016.

[33] Expressen, Britta Svensson En politiker med ansvar. Available at: http://www.expressen.se/kronikorer/britta-svensson/britta-svensson-en-politikermed-ansvar. Accessed on: 28 Dec. 2016.

[34] Statens Offentliga Utredningar, Sverige och tsunamin - granskning och förslag. Available at: http://www.regeringen.se/sb/d/5266/a/54279. Accessed on:28 Dec 2016.

[35] Dagens Nyheter, Göran Persson är skyldig oss en förklaring. Available at: http://www.dn.se/ledare/goran-persson-ar-skyldig-oss-en-forklaring. Accessed on: 28 Dec. 2016.

[36] Socialdemokraterne Valanalys. Available at: http://www.socialdemokraterna.se/ upload/Rapporter/Valanalys/Slutrapport_valanalys_070329.pdf. Accessed on: 28 Dec. 2016.

[37] Sveriges Radio, De borgerliga: Tsunamin orsak till Freivalds avgång. Available at: http://sverigesradio.se/sida/artikel.aspx?programid=83\&artikel=820784. Accessed on: 28 Dec. 2016. 